\title{
Conceptualizing Death: How Do Children in Turkey Understand Death?
}

\author{
A. Reyyan Bilge ${ }^{1}$, Rümeysa Öztürk ${ }^{2}$
}

Bilge, A. R., \& Öztürk, R. (2021). Conceptualizing death: How do children in Turkey understand death. Nesne, 9(20), 221-239. DOI: 10.7816/nesne-09-20-01

Keywords
Children and death,
death concept,
development of death
concept, parental
communication

Anahtar kelimeler Çocuk ve ölüm, ölüm kavram1, ölüm kavramının gelișimi, ebeveyn iletişimi

\begin{abstract}
Death is a hard concept to understand and a delicate subject to talk about, especially with children. The primary purpose of the current study was to investigate the development of the death concept in children between the ages of 3-10. We also aimed to examine the influence of parental communication in the concept's development. Fifty-four children $(M=6.44 ; 55.6 \%$ girls, $44.4 \%$ boys $)$ and their parents $(N=$ 37; 6 fathers, $16.2 \%$ ) were recruited. Children were interviewed one-on-one to evaluate their cognitive and emotional understanding of death. Moreover, their parents were administered a questionnaire to assess how they communicated the concept to their children. We found that older children (7-10 years) grasped some cognitive subcategories of death better than younger children (3-7 years). Our results also showed that both younger and older children had better cognitive and emotional comprehension of the concept if their parents have communicated it to them. These findings suggest that talking to children about death, in an age-appropriate way, helps them perceive the concept better. Age-appropriate communication, especially on an important topic such as death, can further be discussed in terms of social policy.
\end{abstract}

\section{Ölümü Kavramsallaștırmak: Türkiye’deki Çocuklar Ölümü Nasıl Anlıyor?}

Öz

Ölüm, özellikle çocuklar için, anlaşılması zor bir kavram ve hassasiyetle konuşulması gereken bir konudur. Bu çalışmanın temel amacı 3-10 yaş aralığındaki çocuklarda ölüm kavramının gelişimini araştırmaktır. Kavramın gelişiminde, ayrıca ebeveynlerle çocuklar arasındaki iletişimin etkisi de incelenmiştir. Elli dört çocuk (Ort.: 6,44; 30 kız, 24 erkek) ve ebeveynleri (N=37; 6 baba, \% 16.2) araştırmaya katılmıştır. Çocukların ölüm anlayışlarının bilişsel ve duygusal bileşenlerini değerlendirmek için birebir görüşmeler yapılmıştır. Ebeveynlerinden birine de ölüm kavramını çocuklarına nasıl ilettiklerini değerlendirmek için bir ölçek uygulanmıştır. Büyük çocukların (7-10 yaş) ölümün bilişsel alt kategorilerinden bazılarını küçük çocuklardan (3-7 yaş) daha iyi kavradığı bulunmuştur. Sonuçlar, ayrıca, ebeveynleriyle ölüm konusunu konuşmuş olan küçük ve büyük yaş gruplarındaki çocukların ölüm kavramını daha iyi anladıklarını göstermiștir. Bu bulgular, çocuklarla, yaş gruplarına uygun olarak, ölüm hakkında konuşmanın bu kavramı algılamaya yardımcı olduğunu göstermiştir. Yaşa uygun iletişim, özellikle ölüm gibi zor bir konuda çok önemli olup sosyal politikalar açısından değerlendirilmelidir.

Article History

Arrived: October 2, 2020

Resived: February 19, 2021

DOI: 10.7816/nesne-09-20-01

Accepted: March 4, 2021

${ }^{1}$ Asst. Prof., Istanbul Medipol University, Department of Psychology, reyyan.bilge(at)medipol.edu.tr, ORCID: 0000-0003-2105-0122 ${ }^{2}$ Graduate Student, Tufts University, Child Study and Human Development, rumeysa.ozturk(at)tufts.edu, ORCID: 0000-0003-0339-9267 
Children play peek-a-boo, hear Snow White, watch The Lion King or play Angry Birds. These games or stories are age-appropriate activities, however their direct reference to death is easily unnoticed. Interestingly, some suggest that the sudden disappearance and appearance of the external environment in peeka-boo, which is one of the earliest plays that infants engage in, insinuate death (Maurer, 1966). Fairy tales such as the Snow White revolve around the challenging life of an orphaned princess (Lamers, 1995). In the Lion King, there is an intense scene based on the death of the protagonist while the main goal of the Angry Birds is to kill the pigs. Regardless of the abundant exposure to death, it remains to be a taboo. Research shows that adults are not eager to talk about death related topics to their children (Nguyen \& Rosengren, 2004). Nevertheless, children are somehow exposed to the concept early on. Simply assuming that they cannot understand death or denying them answers is not going to enable a healthy conceptualization of the notion. Children might not understand death the same way adults do. However, adults need to realize how much children (can) understand and what they need to know. These answers will ensure effective communication between adults and children, which in turn is going to teach coping mechanisms should they encounter death. The current study aims to investigate how children from different age groups understand death taking parental influences into account.

Death experience can have a negative impact on one's psychological wellbeing. Daily functioning is adversely affected by the loss of a loved one and death experience can increase anxiety (Dettloff, 2012; Miller, Rosengren \& Gutiérrez, 2014). While a death-related event disturbs functioning of adults, children can be more adversely affected because their cognitive capacity and social context make them more vulnerable (Corr, 1995; Corr \& Balk, 2010; Çam et al., 2018). Death could be encountered either vicariously or directly. In vicarious encounters, children will have second-hand experiences via media coverage or video games whereas with direct exposures, they have their grandparents, parents, siblings, relatives, friends or pets die and these are harder to cope with than other losses (Çam et al., 2018). The death of a parent, especially during preschool years, can be a risk factor for adulthood depression (Berg et al., 2016). If a child encounters death through a sudden or unexpected first-hand occurrence, it leads to stress, anger or depression (McGuire et al., 2013). However, the loss of a parent can produce an adaptive response such as resilience (Layne, Kaplow, Oosterhoff, Hill \& Pynoos, 2018). Therefore, we need to address protective factors and positive changes (Calhoun \& Tedeschi, 1999; Şimşek Arslan et al., 2020) along with risk factors when addressing future psychological problems of bereaved children.

It is important to examine how children understand death since it serves many functions. First, it will provide insight as to how the information on such a concept is processed. The concept is complex and multifaceted with many subcategories and factors affecting its formation and comprehension. Death conceptualization is processed through grasping cognitive and emotional components as well as external factors such as parental communication. Investigating these components and factors will provide invaluable insight on the children's comprehension capacity. Second, it will be informative for the caregivers in addressing children's death related questions in a developmentally appropriate way. Responding to a child in a language well above her years might be more harmful than helpful. Furthermore, if the inquiries of the child are not satisfactorily explained it might upset her more. Third, children will best be shielded from the negative effects of loss through close examination of the concept's development. Understanding how children cognitively and emotionally grasp this concept will help researchers and clinicians in establishing assessment methods, coping strategies, and intervention programs for the bereaved and developing educational material for the inquisitive. 
Studies on children's death conceptualization started at around 1930s following World War I and developed gradually after World War II. The first research wave had a psychoanalytic perspective, which mainly focused on the reactions of children towards death. These researchers used techniques such as openended questions and interpretation of drawings as their methodology. Their efforts revealed a difference in the comprehension of death between children and adults (for a review see Slaughter, 2005). The second wave emerged with the rise of the cognitive revolution. Children's conceptualization of death was then theorized to follow a stage-based development (Nagy, 1948 as cited in Corr, 2010). Maria Nagy proposed three chronologically defined stages for the development of death concept where children younger than 5 years of age (Stage 1) cannot understand that death is definitive and life is completely over. Children between 5 and 9 years of age (Stage 2) personify death and identify it with dead people. They understand that it is final, nevertheless, continue to assume that people can escape from it. However, children older than 9 years (Stage 3 ) comprehend that death is universal and an inevitable process resulting in cessation of life (for a review see Hopkins, 2014).

Cognitive components that are necessary to conceptualize death were discussed in several studies (Engarhos, 2012; Panagiotaki et al., 2018; Panagiotaki et al., 2014; Slaughter, 2005; Slaughter \& Griffiths, 2007; Speece \& Brent, 1984). Investigating when and whether children grasp each component, methods derived from the psychoanalytic perspective, such as conducting interviews, or having children draw pictures, define terminologies, or write stories, were used. Some researchers suggested broader components of universality and finality (Corr, 1995; Speece \& Brent, 1996) that branch into all-inclusiveness, inevitability, and unpredictability (Corr, 2010), irreversibility, and non-functionality (Brent \& Speece, 1993). Others define irreversibility, non-functionality, and universality to be the key components (Hunter, 2005; also see Speece \& Brent for a review, 1984). Causality is also listed among the components of a developed death concept (Rosengren et al., 2014). To sum up, overarching cognitive concepts of death were irreversibility, nonfunctionality, inevitability, applicability, and causality.

Irreversibility means that a dead person won't return back to life and to test children's understanding of this concept, they are asked whether an entity that has died would be able to come back to life. Children who do not grasp this component might think of death as sleep and misunderstand it as temporal. Nonfunctionality expresses that the functions of the body and mind cease after death, asking children whether a dead entity would be able to eat, drink, speak, dream, know, etc. Both irreversibility and non-functionality refer to the idea of finality. The inevitability idea indicates that nobody can escape from death. Allinclusiveness can also be considered as universality/applicability stating that death is inclusive, universal, and applicable to all ages and living entities. To test children's comprehension of this subcomponent they are asked whether every living thing dies. Both inevitability and applicability refer to the idea of universality. While applicability examines children's comprehension that death is applicable to every living thing, inevitability checks whether any living entity can escape from it. Causality meanwhile points to an understanding of the biological cause of death. To sum up, the cognitive perspective asserted that a child is required to understand all cognitive components to develop a mature understanding of death (Engarhos, 2012; Panagiotaki et al., 2018; Panagiotaki et al., 2014; Slaughter \& Grifftihs, 2007).

A stage-based theory of development on death conceptualization suggests that children understand the concept more as they get older (Nagy as cited in Corr, 2010). However, there is disagreement about the age of the mature understanding of an overall death concept as well as comprehension of different components. Kenyon (2001) summarized that at the age of 10, nearly all children understood irreversibility, universality, non-functionality, personal mortality, and causality. Speece and Brent (1996), however, proposed that by the 
age of 7 most children understood universality, irreversibility and non-functionality components. Research also showed that even children at the age of 4 showed partial understanding of finality, universality, nonfunctionality and causality. Furthermore, their comprehension levels increased when they were 5- and 6- yearolds (Rosengren et al., 2014). Nguyen and Gelman (2002) showed that all children between the ages of 4 and 6 showed an understanding of universality, inevitability, finality, and causality for a plant but not for a person. To summarize, the time between 4- and 10-years was evaluated to show dramatic change in the comprehension of death concept. Moreover, children showed a similar pattern in learning order of the components (Panagiotaki et al., 2018; Panagiotaki et al., 2014; Slaughter \& Griffiths, 2007). They grasped irreversibility first, followed by cessation (non-functionality), inevitability, applicability, and finally causation, in this order.

Studies focused on cognitive development of the concept, however emotional component such as empathy was considered to be another factor to maturely comprehend death (Slaughter, 2005). Psychoanalytic perspectives mainly focused on the reactions of children (who experienced loss) towards death. Children, as early as two years, understand simple emotions such as happiness and sadness, and even express their emotions (Harris, 2008). Gutiérrez and colleagues (2014) measured emotional understanding of death. They used a book that included photographs about humans, animals, plants, inanimate objects, and a character named "Terry". They then asked hypothetical questions regarding the death of one of the photographs and the child's emotional understanding was measured. As a result, majority of the children, regardless of age, expressed that Terry would feel sad if her relative $(86 \%)$, pet $\operatorname{dog}(85 \%)$, or a house plant $(73 \%)$ died. The Harvard Child Bereavement Study (Silverman \& Worden, 1992; 1993; Worden \& Silverman, 1996) was conducted with children whose parents passed away either through an expected or an unexpected cause. The study compared bereaved and non-bereaved children on the emotional effects of losing a parent to death. Children were examined at three points: four months, a year, and two years after their loss. The differences between the groups were more noticeable after two years, where the bereaved children showed higher levels of social withdrawal, social problems, and anxiety and lower levels of self-esteem and self-efficacy compared to the non-bereaved (Worden \& Silverman, 1996). One of the findings from the bereaved group was that the majority of them continued to have relationships with their deceased parents; they either saw them in their dreams, or talked about them (Silverman \& Worden, 1993). Unexpected sudden death was another factor that put children at risk for developing these symptoms, especially within the first year of their loss (Worden \& Silverman, 1996). However, factors such as child's healthy relationship with the surviving parent, having a supportive family and a stable environment, being responsive to the child's grief process, and sticking to the daily pretrauma routines will protect the bereaved child from developing psychological illnesses in the future (Erden \& Gürdil, 2009; Layne et al., 2018). These protective factors enabled posttraumatic growth Calhoun \& Tedeschi, 1999) in children and adolescents who lost one of their parents (see Şimşek Arslan et al., 2020 for a review). Death of a loved one, therefore, is not the only factor that causes one's behavioral or emotional problems. Still, these studies signify early years of life as a sensitive time period in terms of the emotional understanding and impact of death in a child's life. Moreover, research on emotion highlights the fact that death comprehension would not be complete without the emotional or social factors.

The role that parents and culture play on the development of the death concept was initially underestimated. It later attracted attention (Astuti \& Harris, 2008; Engarhos, 2012; Gutiérrez et al., 2014; Harris, 2011; Legare et al., 2012; Nguyen \& Rosengren, 2004; Panagiotaki et al., 2014; Renaud et al., 2013) stressing the notion that a death concept cannot be fully comprehended without acknowledging children's immediate and cultural environments (Nguyen \& Rosengren, 2004). Ecological Systems Theory proposed by Bronfenbrenner (1979) states that the development of a child can be understood by studying levels of environments he/she interacts with: micro (immediate environment), meso (connections), exo (indirect 
environment), and macro (socio-cultural effects and chronosystems) systems. A child will simultaneously engage in these systems, from the most immediate towards the outward, broader surroundings. Each system interacts with one another shaping how a child develops over time. Microsystem is the most significant influencer, since it is the most intimate "home" environment directly interacting with the child (Maccoby, 1992). More supportive microsystems will nurture the development of a child more. Based on this theory, the current study aims to understand whether parental socialization (micro) and cultural factors (meso, exo, and macro) influence the development of death conceptualization.

Parental socialization refers to the social learning of children as they are influenced by their parents and is highly emphasized in the developmental psychology literature (Engarhos, 2012; Gutiérrez et al., 2014; Hunter, 2005; Nguyen \& Rosengren, 2004; Renaud et al., 2013). However, the effect of parental socialization on children's understanding of death has not been vastly studied. One way to study parental socialization is through examining parent-child communications. Different studies observed and analyzed conversations, particularly on death, between parent and child (Engarhos, 2012; Gutiérrez et al., 2014; Renaud et al., 2013). In one study, the majority of children (87\%) was found to have experienced death at some level (media, family, death of a family pet). Seventy-five percent of the parents had talked about death with their children and the first conversations started at 3-3.5 years of age. Parents did not report any behavioral change in children after these conversations. Parents, who provided explanations such as continued existence after life rather than biological causes were more satisfied with their own explanations (Renaud et al., 2013). Engarhos (2012) also surveyed parents about their children's comprehension of death and fear. Parent-child dyads watched a video from Sesame Street and parents were asked to naturally converse with their children. Children were then interviewed on cognitive components as well as fear and general anxiety. In the study, parents were quite accurate in evaluating their children's comprehension of death. In another study, Gutiérrez and colleagues (2014) included cognitive, affective, cultural, and parental factors when investigating death comprehension of children. Findings showed that while $2 / 3$ of the parents used reassuring statements, all the parents used facts and biological, emotional/psychological, or religious explanations. Interestingly, in contrast to Engarhos (2012), the findings showed that children mostly understood cognitive components of death even though their parents thought to the contrary (Gutiérrez et al., 2014).

Cultural factors that affect a child's values and beliefs constitute the macrosystem in Bronfenbrenner's model (1979). Macrosystem, unlike the microsystem with direct influence of the parent, indirectly affects a child's development. The belief system that the child grows up in influences the development of the death concept. In many societies, religion prominently shapes one's beliefs about death (Astuti, 2011). The majority of the adults in the US were reported to believe afterlife, in some form (Greeley \& Hout, 1999). In Turkey, majority of people are Muslim (DIBB, 2014). Ratio of Muslims in the population change according to different reports and years, and the latest poll conducted by Optimar reported this ratio to be $89.5 \%$ (Özkök, 2019). Despite the high ratio, people who rate themselves as highly religious were $10 \%$ and who identified themselves as religious were 51\%, as reported by Konda's 2018 survey (Kenyon, 2019). In Turkey, Islam is the most common religion. However, attitudes toward religion and religious practices vary across different geographical regions, socioeconomic status and ethnicity. Nevertheless, beliefs in Allah (one God in Islam) and afterlife or references to religious notions could very well be ingrained in the culture (Astuti, 2011; Bronfenbrenner, 1979; Greeley \& Hout, 1999).

Children and adults think about death as two sides of the coin; 'the end of life' with a biological reasoning and 'a new start' with a spiritual reasoning (Astuti \& Harris, 2008). Harris (2011) proposed a dualistic approach to death emphasizing that these two seemingly opposite reasonings, biological and spiritual, 
could simultaneously exist in children, which was later supported by Callanan (2014). Children supplement their biological reasoning with a more religious concept as they get older (Harris, 2011; Richert \& Harris, 2006). Researchers described the death of a grandparent to children between 7-to-11-years, with a secular or a religious narrative (Harris \& Giménez, 2005). Children were then asked to judge whether bodily and mental functions of the deceased continue after death. Mental functions (e.g., thinking) were considered to continue after death more than bodily functions (e.g., speaking). Older children more frequently thought that bodily or mental functioning continued after death. Moreover, children who were given a religious narrative more frequently thought that functions continued after death, as opposed to the ones who were given a secular narrative. When children thought that the functions ceased, they provided biological explanations. However, when they thought that the functions continued after death, they provided religious or metaphysical explanations. Consistent with the proposed dualistic thinking, religious and biological systems pertaining death, cohabited in the minds of the older children (Harris \& Giménez, 2005). Furthermore, religious explanations seemed to override biological justifications especially for older children and adults (Astuti \& Harris, 2008; Harris, 2011; Harris \& Giménez, 2005; Richert \& Harris, 2006).

Other studies also showed the effect of religious upbringing and beliefs on children's understanding of death. Corriveau and colleagues (2015) investigated 5 and 6-year-old children attending religious and secular schools. Children, similar to earlier studies, were provided with realistic and religious stories. Realistic stories included ordinary events with a real protagonist. Religious stories had seemingly impossible events occurring with divine interventions. As a result, children who go to church or religious schools judged the protagonist in religious stories to be a real person, whereas children who go to secular schools judged the protagonist to be a fictional character. Therefore, children's differentiation between reality and fiction were highly affected by their prior exposure to religious ideas (Corriveau et al., 2015). Children with religious backgrounds also showed positive emotions and attitudes towards death, according to a study that was done with Chinese pre-school children (Wong, 2019). Panagiotaki and colleagues (2014) investigated understanding of cognitive components by comparing 4-to-7-year-old- children from different cultural and religious backgrounds. They included White British and British Muslim children living in urban areas in London and Pakistani Muslim children living in rural areas in Pakistan. Consistent with the literature, they found that irreversibility was grasped first and causality was the last. They also found that irreversibility was understood earlier by Pakistani Muslim children. Furthermore, older age children (age 6-7) scored better on applicability and inevitability questions than younger age children. However, there were no differences in comprehension of inevitability, applicability, irreversibility, and cessation between British Muslim and White British children. This could be related to similar factors in urban life such as media exposure, schools, and socio-economic status (Panagiotaki et al., 2014). Differences and similarities between Pakistani and British children were explained through cultural factors and the environments they were brought up in. Furthermore, children developing in different cultural environments have different experiences with death, which in turn affect their understanding of the concept. Children living in more peaceful areas of the world would be exposed to death differently than children who have experienced war, terrorist attacks, or other natural disasters. Thus, it is safe to assume that children who have had first-hand experiences of death would have different comprehensions of the concept (Wass \& Towry, 1980). Current study will examine death conceptualization of different age children residing in Turkey.

The way children conceptualized death has been studied more in Western countries such as the US (Rosengren et al., 2014) or the UK (Panagiotaki et al., 2014). Research on this issue in Turkey is very scarce. Taking into consideration that the majority of the population are Muslims (88.5\%; Minority Report, 2015), who believe in Allah (98.7\%) and afterlife (96.2\%) (DİB, 2014), it would be worthwhile to investigate how 
children develop the concept of death and whether parent-child communication has an effect on its development. Moreover, there is war and terror-related media coverage since large cities have been targets of terrorist attacks. Turkey has had suffered from natural disasters such as earthquakes and floods. Being in a seismically active area, earthquakes sometimes lead to death tolls. As a consequence, children in Turkey might have first-hand or vicarious experience with death related events, which could potentially influence their understanding of the concept. Furthermore, according to the United Nations Refugee Agency's report on September 2020, Turkey has the largest refugee population in the world with 3.6 million Syrians (UNHCR, 2020, September). Özer and colleagues (2013) conducted research in Islahiye camp in Gaziantep with Syrian refugee children between the ages of 9 and 18 about their war experiences. They reported that $74 \%$ of children experienced the death of a close one. Extending the literature, a quantitative research with 572 children between the ages 8 to 13 used the Death Attitude Scale and found that children's understanding of death is positively associated with their cognitive development (Y1lmaz, 2012). There are also a few review papers about the grieving process (Yıld1z, 2004), death education (Erden \& Gürdil, 2009; Tanhan, 2013), and the effect of death on children (Köylü, 2004; Sezer \& Saya, 2009). Erden and Gürdil's research both thoroughly examines responses of children and adolescents to traumatic war experiences and suggests a psycho-social intervention geared towards different age groups (2009). However, there is no research that investigates the development of death conceptualization in Turkey, let alone including cognitive, emotional, and parental factors. To sum up, it is safe to assume that children in Turkey are exposed to death either through first-hand experiences or vicariously. Knowing how children conceptualize death, should they have any questions about the concept, parents and teachers can provide age-appropriate explanations hence protect them from possible negative effects.

\section{Current Study}

The period between 3-10 years of age is indicated to be a significant time where the development of the death concept can be more easily observed (Nguyen \& Gelman, 2002; Rosengren et al., 2014; Slaughter, 2005). Current study investigated how the death concept developed across different age groups by categorizing children into younger (3-7 yrs) and older (7-10 yrs) age groups. The sample consisted of Turkish children and their parents. There are many factors that might influence a child's understanding of death. The current study included children's chronological age, cognitive and emotional understanding pertaining to that age group and parental socialization. Therefore, it is a highly important work in this field and to our knowledge is the first study that examines all these factors.

There are two hypotheses in the study. We predict that older children will comprehend cognitive and emotional components of death better than younger children. However, based on the dualistic thinking idea suggested by Harris and colleagues $(2011,2005)$, older children of this sample, considering the widespread religious notions, might clearly differentiate some of the cognitive components. We also predict that parental socialization will be a factor influencing a child's conceptualization of death. If parents communicate death to their children, their children will comprehend death earlier than children with whom the issue has not been discussed before. Incorporating the factors examined in this study, we aim to provide knowledge on children's death understanding for educators, families, and social workers. This is also the first study conducted in Turkey that aspires to understand the underlying cognitive and emotional components of death. 


\section{Method}

\section{Participants}

Fifty-four children, ages 3-10 participated in the study. Of these participants, there was a total of 30 girls $(55.6 \%)$ and 24 boys $(44.4 \%)$. The mean age of the children was 6.44 years, and the standard deviation was 1.77. Thirty-one of the children were between 3-to-6 years and 11 months $(\mathrm{M}=5.23, \mathrm{SD}=1.09)$ and 23 of the children were between 7-10 years $(\mathrm{M}=8.09, \mathrm{SD}=1.04)$. Distribution of Gender by Age is shown in Table 1. Thirty-seven parents (31 mothers, $83.8 \%$; 6 fathers, $16.2 \%$ ) participated in the study. The numbers of children and parents do not match because i) some parents had multiple children in the study, and ii) not all parents completed the questionnaires.

Table 1

Distribution of children's Gender by Age

\begin{tabular}{|c|c|c|c|c|c|}
\hline & & \multicolumn{4}{|c|}{ Age $(N=54)$} \\
\hline & & \multicolumn{2}{|c|}{$\begin{array}{c}3-6.11 \text { ages (younger) } \\
M=5.23, S D=1.09\end{array}$} & \multicolumn{2}{|c|}{$\begin{array}{c}7-10 \text { ages }(\text { older }) \\
M=8.09, S D=1.04\end{array}$} \\
\hline & & $N$ & $\%$ & $N$ & $\%$ \\
\hline \multirow[t]{2}{*}{ Gender } & Boy & 16 & 29.6 & 8 & 14.8 \\
\hline & Girl & 15 & 27.8 & 15 & 27.8 \\
\hline
\end{tabular}

Children and parents were recruited through convenience sampling. Researchers contacted three private pre- and elementary schools, located in the Asian side of İstanbul, due to their proximity to ... University. All children were interviewed individually in a quiet room at their schools or at the ... Lab at ... University. Their parents signed the consent forms. When children were interviewed in the lab, their parents filled the survey in a separate room. The parents filled the survey and returned it back to school with consent forms if children were interviewed at schools. The study was approved by the Institutional Review Board of Istanbul Şehir University.

\section{Measurements}

Three stories were created to investigate children's understanding of death. Children were interviewed one-on-one, following earlier procedures (Panagiotaki et al., 2014; Rosengren et al., 2014; Slaughter, 2007). Each story had an imaginary child sharing the same age and gender as the participant who experiences death of a(n) aunt/uncle, cat, and flower. Hand drawn characters, which were named random letters from the alphabet such as C, J, M, etc. were used in stories (see Figure 1a).

We asked questions to comprehend cognitive and emotional components of children's death concept for each entity (aunt or uncle/cat/flower). Questions on the ideas of inevitability (does A's aunt or uncle/cat/flower have to die?), applicability (can A's aunt or uncle/cat/flower live forever?), irreversibility (can A's aunt or uncle/cat/flower come back to life?), non-functionality (can A's aunt or uncle/cat/flower drink water, grow, move, breathe, dream, think want something?), and causality (why did A's aunt or uncle/cat/flower die?) were included in the interview. To measure the emotional component of death comprehension, empathy questions (how does A feel about the death of this aunt or uncle /cat/flower?) were included (please see Table 2 for a list of questions). Presentation order of the death entity is counterbalanced across participants. Before and after each story children were asked to rate their mood on a Likert-type scale with smiley-faces, where 1 corresponded to very happy and 5 to very sad (Figure 1b). 


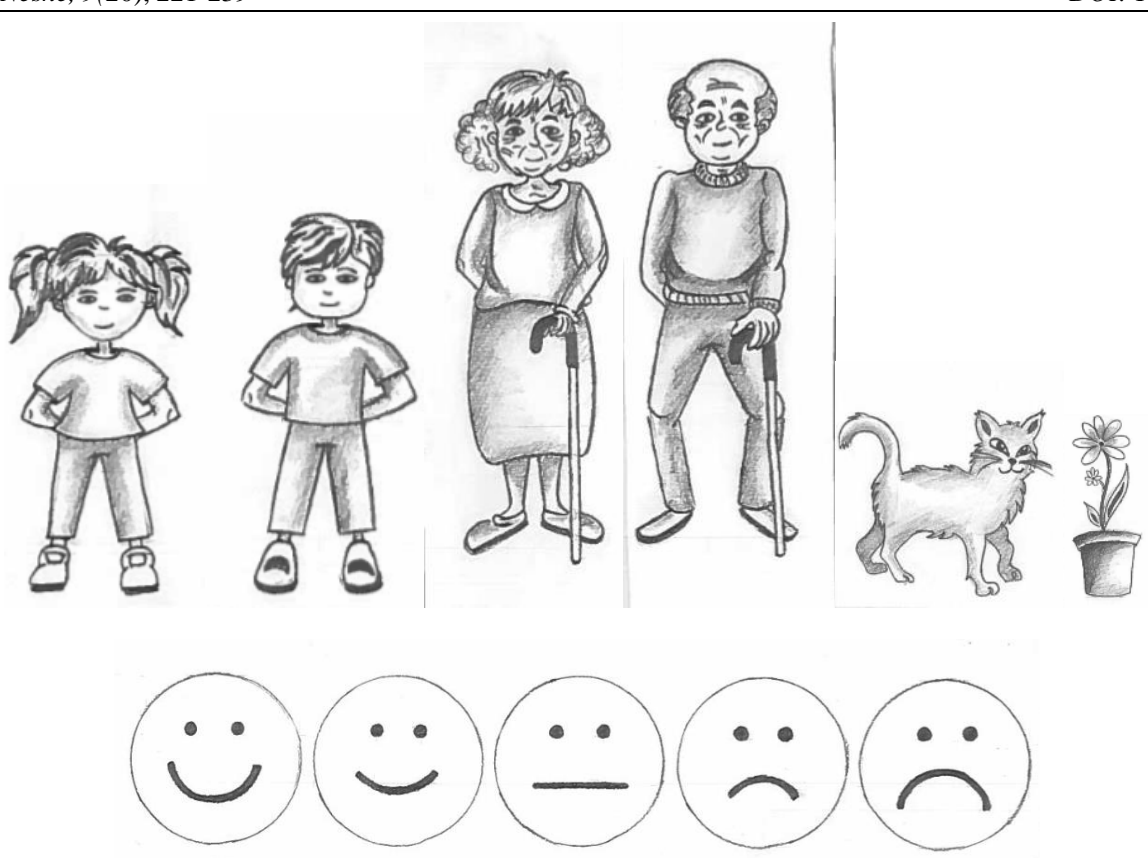

Figure 1a. (top row) depicts hand-drawn characters of imaginary children as well as aunts and uncles, flowers, and cats that die in interview stories. Figure $1 b$ (bottom row) shows the child-friendly version of the Likert type scale to we used for empathy ratings. The face on the far left denotes 1 and being very happy and the one on the far-right figure points to 5 and being very sad.

Table 2

Coding Scheme for Pass and Fail Responses to an Entity

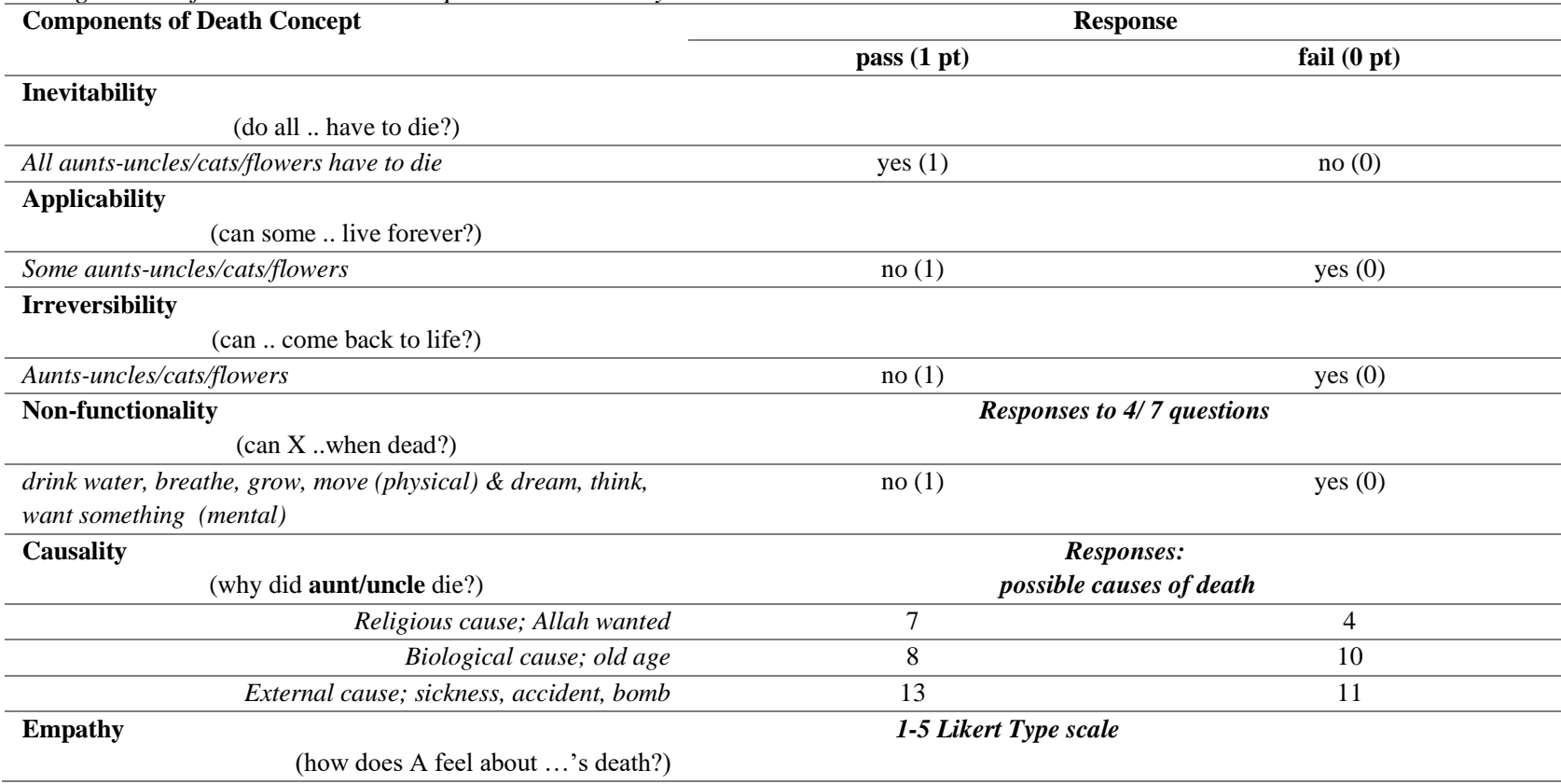

Parents were given a survey consisting of demographic questions such as age, gender and education status. They also received questions about whether their children have experienced death (family, friend, pet, etc.), whether they talked to their children about death, and whether they used additional materials in 
explaining the death concept. Moreover, they were asked to state their religion if they identified themselves with one and as a follow-up question were asked to rate their level of religiosity.

\section{Procedure}

Children came to the interview room with their parents, who signed the consent form on their behalf. Before starting with the interview, we provided some time for the child to get comfortable with the environment. They then were asked whether they would like to hear a story and they assented verbally. They were presented with three stories about an imaginary character whose aunt/uncle, cat, and flower passed away. Children answered questions for each entity. They then listened to an uplifting story about other imaginary children riding bicycles and having a fun day. Before and after each story and at the end of the uplifting story, children rated their moods (see Figure 1b). The whole experiment approximately took 15-20 minutes. The interviews were recorded with parental permission for further transcription and coding. Upon consenting to participate in the study both for themselves and their children, parents were also administered a survey. They had the option to complete the survey in the lab or at home. Participants were fully debriefed. In the debriefing, contact information for clinicians were included in case children have negative moods after the experiment. They were Also presented with compensatory toys.

\section{Coding}

Data was collected in Turkish. Voice recordings of the interviews were transcribed and coded for analyses. Children were individually scored for each cognitive (inevitability, applicability, irreversibility, nonfunctionality, and causality) and emotional (empathy) component. The coding scheme can be seen in Table 2 . For inevitability (does $\mathrm{X}$ have to die?) question, participants were given a score of 1 for a pass (yes) and 0 for a fail (no). For example, if a child responded as "no, a flower does not have to die", then she received 0 for that entity and component. Overall, a child received 1 or 0 for each entity and the average score for all three entities was computed. An average score for inevitability, applicability, irreversibility, and non-functionality was between 0-1, where closer to 1 indicated better comprehension (please see Table 3 for means and standard deviations of each subcomponent per entity).

When children understood applicability (can X live forever?) and irreversibility (can X come back to life?) components, they were given 1 (no) for passed and 0 (yes) for failed answers. A total score for inevitability, applicability, and irreversibility was separately calculated by adding pass/fail scores for each entity per component. For non-functionality, children were asked about the cessation of physical (can X drink water, grow, move, breathe?) and mental (can X dream, think, want something?) functions after death. A child received a passing score of 1 if she said no to 4 out of 7 questions, otherwise she received a score of 0 . For causality (why did X die?) component, we first grouped the responses based on the most uttered. The main reasons of death according to the children are listed (please see Table 2 for a list of questions and the frequency of responses). The answers clustered around Allah and other religious references (e.g., fate, the time in this earth, afterlife), biological causes (e.g., being old) and external factors (e.g., accidents, bombs, shootings). There were two independent coders and the interrater reliability was $96 \%$.

Empathy score was computed based on the ratings of the child. Mood of the fictitious character were rated on a Likert type scale, where 1 was very happy and 5 was very sad. Average empathy was calculated by adding the scores per entity and dividing it by three, resulting in a score between 1-5. Parental socialization was operationalized by asking parents whether they have communicated death to their children. Parents were given a score of 1 for prior communication on death and a score of 0 for no previous communication, ending in each child having a score of 0 or 1 . 
Table 3

Means (SD) of Death Components by Entity and Age

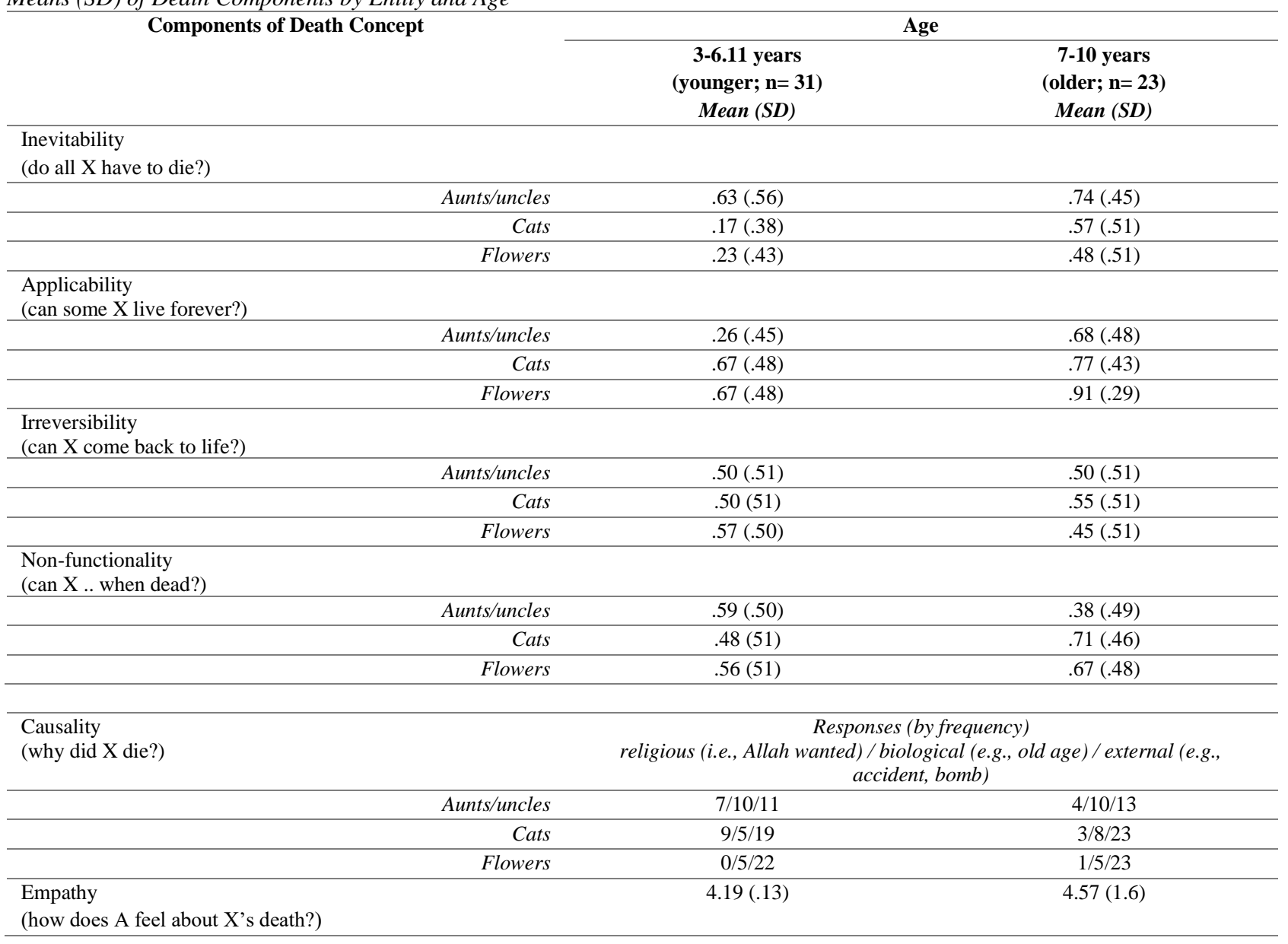

Note. that inevitability applicability, irreversibility, and non-functionality scores range between $0-1$ where 0 is a fail and 1 is a pass. Causality scores are categorized as religious, biological and external and the frequencies are reported. Empathy score ranges between 1-5; 1 being very happy and 5 being very sad.

\section{Results}

Mixed factor ANOVA was used to analyze the effect of Age (younger and older children) and different types of Entity (aunt, cat, flower) on comprehension of cognitive (inevitability, irreversibility, applicability, non- functionality, and causality) and emotional (empathy) components. Age of the children was a betweenparticipant factor. Children 3 to 6 years and 11 months were grouped as younger $(N=31,57.4 \%)$ and the ones between 7-to-10 years $(N=23,42.6 \%)$ were categorized as older. Entity of the fictitious character was a within-participant factor. A mixed 3 (aunt, cat, flower) X 2 (younger vs. older age) ANOVA with repeated measure on entity was separately done for each cognitive (inevitability, applicability, irreversibility, nonfunctionality) and emotional component. For causality a chi-square analysis was done on the frequencies of the responses. Please see Table 3 for the mean scores for each component by Age and Entity.

\section{Inevitability Component of Death}

Mauchly' $s$ test of sphericity indicated that the assumption of sphericity had been violated, $\chi^{2}(2)=$ $7.43, p=.024$, therefore degrees of freedom were corrected using Huynh-Feldt estimates of sphericity $(\varepsilon=$ 
.93). Results showed a main effect of Age on inevitability component, $F(1,51)=8.36, p=.006, \eta^{2}=.141$. Older children understood that all entities have to die significantly more than younger children (Figure $2 b$ ). Results also showed a main effect of Entity on inevitability, $F(1.85,94.39)=10.01, p<.001, \eta^{2}=.164$. Pairwise comparisons indicated that children understood that all aunts/uncles have to die more than they did for cats, $p<.001$, or flowers $p=002$. However, there was no significant difference on their inevitability scores between cat and flower (see Figure 2b). There was no interaction between Age and Entity (aunt, cat, flower).
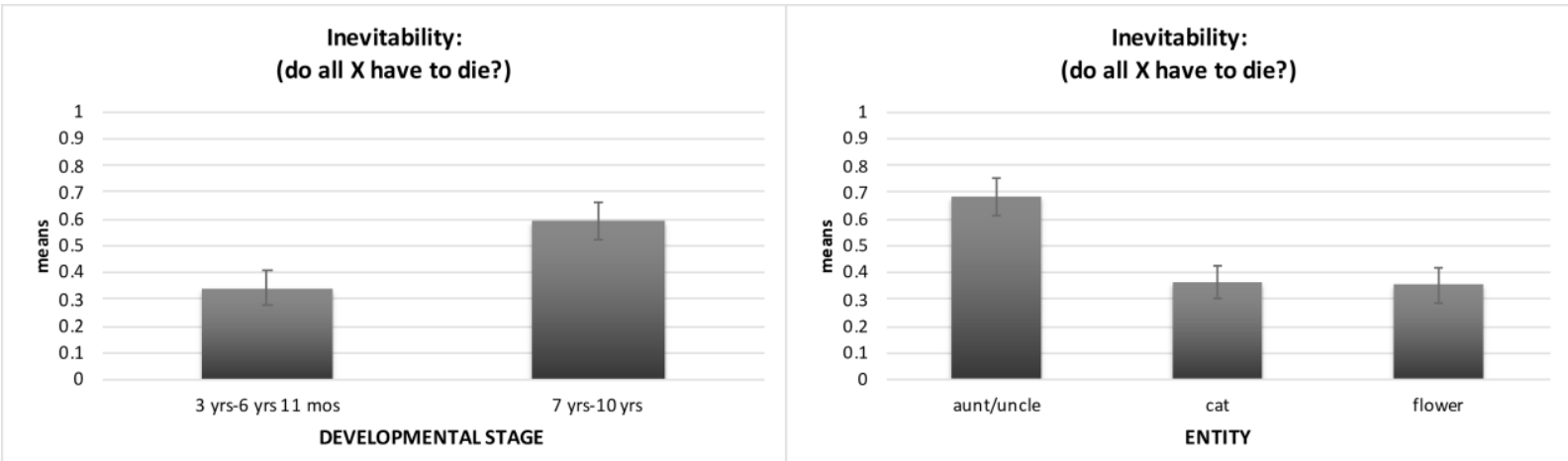

Figure 2. shows children's comprehension of the Inevitability subcategory. Figure $2 a$ (above left) depicts mean understanding rate for 3 -year- to 6 year-11 months-old and older (7-year- to10-year-olds) and Figure $2 b$ (above right) shows children's mean understanding rates for Entity; aunt, flower, and cat.

\section{Applicability Component of Death}

There was a main effect of Age, $F(1,47)=6.83, p=.012, \eta^{2}=.127$. Older children understood that death is applicable to all significantly more than younger children (Figure $3 \mathrm{a}$ ). There was a significant effect of Entity on comprehension of applicability component, $F(2,94)=11.46, p<.001, \eta^{2}=.196$. Children understood that some flowers cannot live forever more than they understood that some aunts cannot live forever, $p<.001$ and that death is applicable to all cats than aunts, $p=.004$. However, there was no significant difference between cat and flower applicability (see Figure 3b). Furthermore, there was no interaction between Age and Entity.

Analyses on Irreversibility component did not show main effects of Entity, Age or an interaction between these factors.

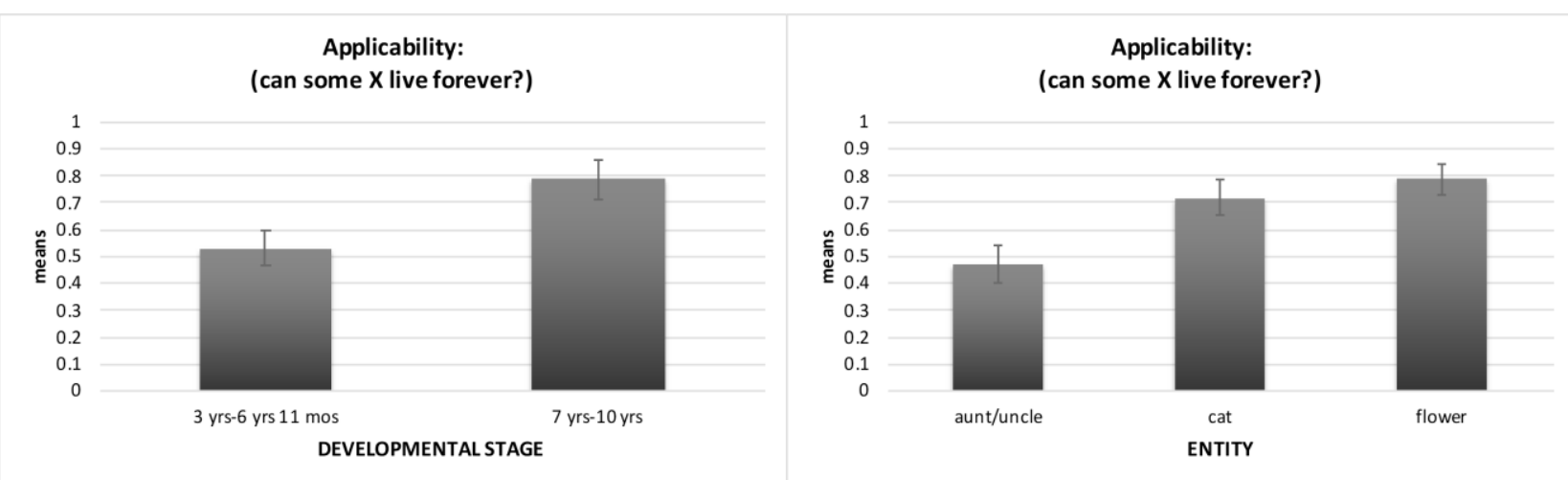

Figure 3. depicts children's comprehension of the Applicability subcategory. Figure 3a (above left) shows mean understanding rate for younger (3year- to 6-year-11 months-olds) and older (7-year- to 10-year-olds) children. Figure $3 b$ (above right) depicts children's mean understanding rates for Entity; aunt/uncle, flower, and cat. 


\section{Non-Functionality Component of Death}

Mean scores of the children were analyzed based on 0-1 scores of the non-functionality component. There were no main effects of Entity or Age. However, there was a significant interaction between Entity and Age, $F(2,92)=4.37, p=.02$, partial $\eta^{2}=.09$. Older children could understand that cats and flowers cannot function (biological and mental functions) when they are dead as opposed to younger children, whereas younger children comprehended that aunts and uncles could not function after death more than older children (see Figure 4). Non-functionality component was also assessed based on separate mean scores of mental and physical aspects, and a cumulative score for non-functionality with a maximum score of 7 . None of these analyses showed significant findings.

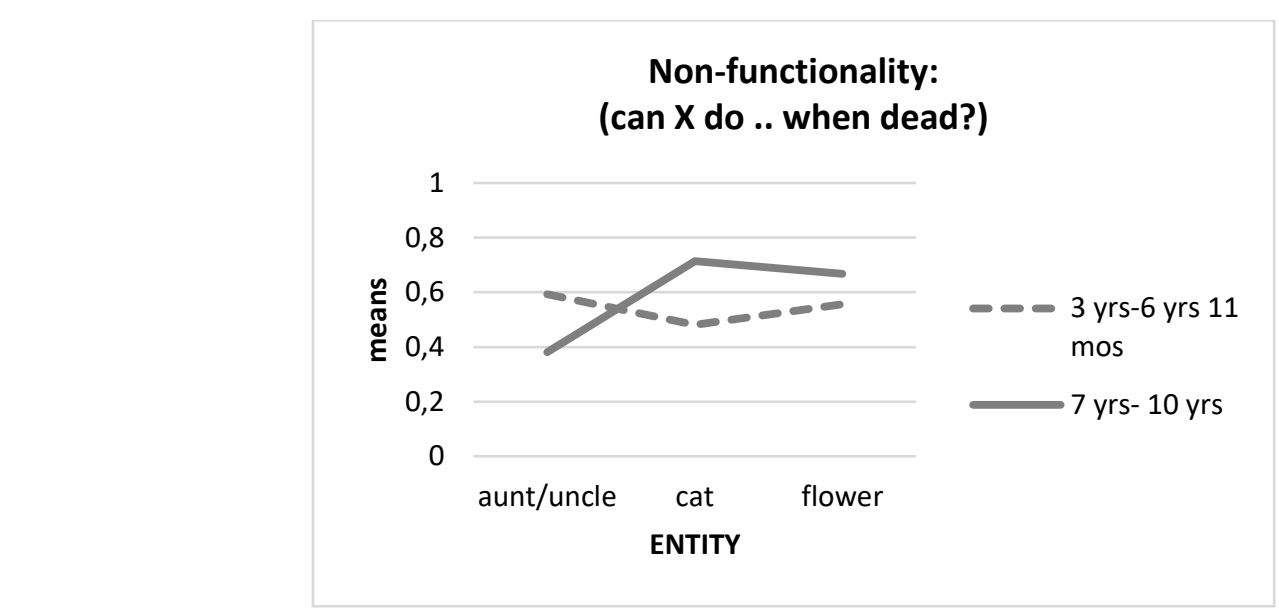

Figure 4. depicts younger (between 3-year- and 6-year-and-11-month-olds) and older (between 7-year- and 10-year-olds) children's nonfunctionality comprehension for different entities (aunt/uncle, cat, and flower).

\section{Causality Component of Death}

A series of chi-square tests were done on causes of death. This analysis provided further understanding into children's conceptualization of death based on their main explanations (see Tables $2 \& 3$ ). There was no significant effect between younger and older children in terms of their religious, biological, or external references. However, response trend showed that the majority of the explanations were external and older children did not make as many religious references as younger children.

\section{Emotional Component of Death}

Emotional state of the children was measured before and after the interviews. On a scale from 1 to 5; 1 being very sad and 5 being very happy, they were as happy before $(M=4.68)$ and after the interview $(M=$ 4.6). There was no significant difference between pre- and post-interview-emotional states, $\mathrm{t}(60)=.15, \mathrm{p}=$ .26 , ensuring that the interviews did not decrease children's mood.

Mean scores of the participants were analyzed on emotional component. Children were asked how the imaginary character in the story would feel in the given death scenario; aunt/uncle, cat or flower of the character. However, there were no significant effects between younger and older children on empathy ratings per either entity. 


\section{Descriptive Statistics of Parents}

Out of 37 parents, 31 of them were mothers $(83.8 \%)$ and 6 were fathers (16.2\%). They did not answer each question thus we will not report all the answers for the sake of brevity. Parents' mean age was $M=34$ $(\mathrm{SD}=4.49)$ and their education levels varied. Seven parents had doctorate or master degrees, 16 had college degrees, 8 graduate high and middle school and there was 1 parent who completed elementary school. Parents reported that 17 children have experienced death, while 9 children have not. The body of religious distribution was homogenous within the parents, consisting of 32 parents all of whom identified their religion as Islam. On a 5-point Likert scale, the mean rating was 3.

\section{Effect of Parental Socialization}

Parental socialization was operationalized by asking the parents whether they had a talk about death with their children before. A series of univariate ANOVAs were used to assess the effect of family talk on each component of the death concept as a function of Age. If parents have talked to their children about death, all children, regardless of their age group, comprehended cognitive components such as inevitability; $F(1,50)$ $=7.73, p=.008$, partial $\eta^{2}=.13$ (Figure 5a), irreversibility $F(1,51)=13.90, p<.001$, partial $\eta^{2}=.21$ (Figure 5b), and non-functionality; $F(1,54)=8.16, p=.006$, partial $\eta^{2}=.13$ (Figure 5c) more. There was no effect of parental communication on the applicability component of death. Furthermore, children had higher empathy scores; $F(1,48)=14.86, p<.001$, partial $\eta^{2}=.24$ (Figure5d), when their parents had talked to them about death. However, a chi-square analysis on causality showed that there was no reliable difference between children whether their parents had talked to them about death or not.

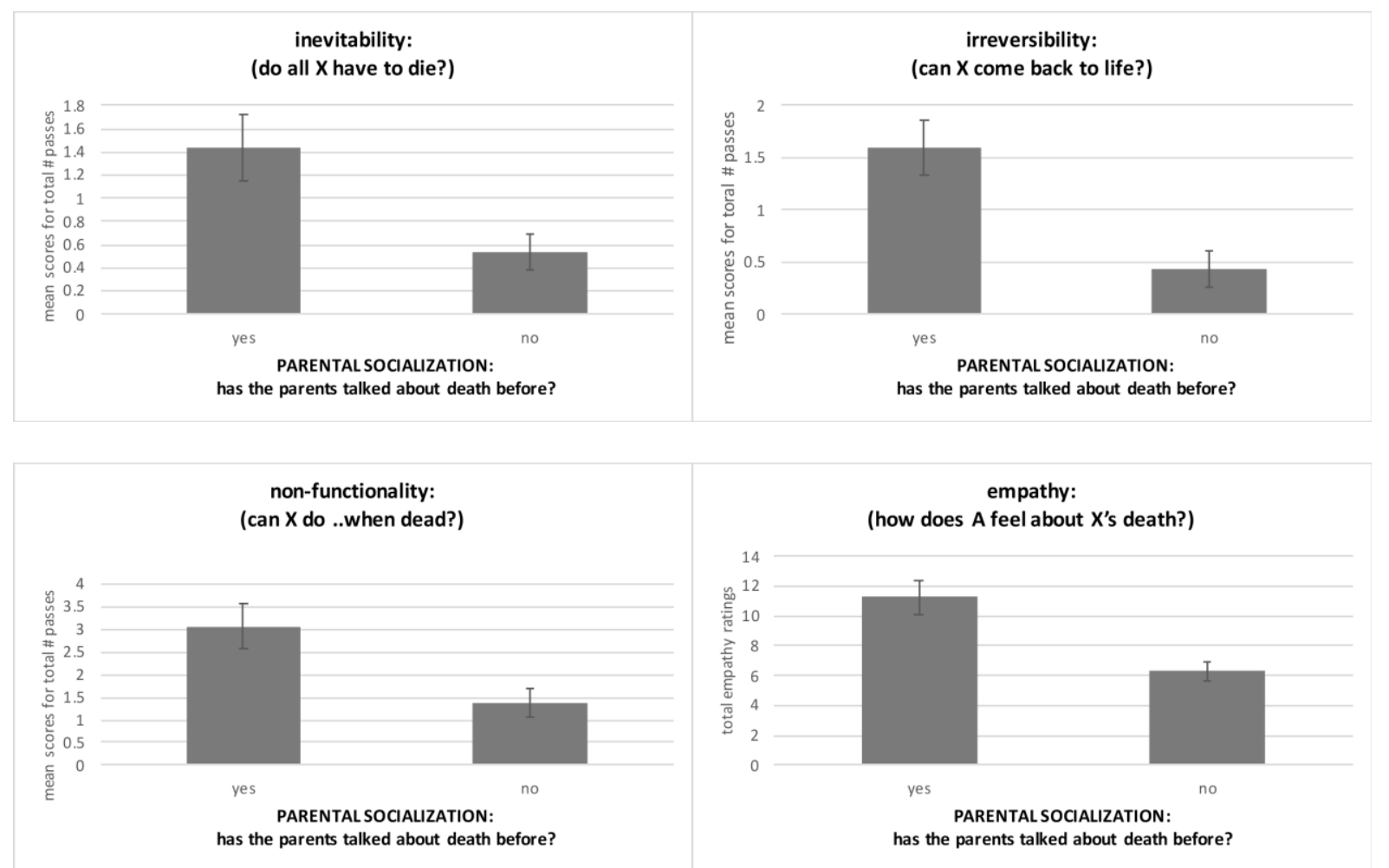

Figure 5. shows cognitive and emotional component scores of children whose parents have talked to them about death and whose parents have not. For inevitability (Figure 5a; left top above) and irreversibility (Figure 5b; right top above), cumulative pass scores were computed, mean scores ranging between 0-3. Non-functionality scores (Figure 5c; left above) were calculated based on the responses to a total of 7 questions. Y axes show the mean frequency of correct responses. Figure $5 d$ (right above) displays the cumulative empathy scores, possible maximum score being 15 . 


\section{Discussion}

The study explored 3-to-10-year-old children's development of cognitive and emotional conceptualization of death and the role of parental socialization in this process. Our first goal was to examine different developmental patterns of death concept between two groups; younger children (3-6 years 11 months) and older children (7-10 years). The study was first experimental study in Turkey investigating the concept of death incorporating both cognitive and emotional components. We found that older children had better comprehension of inevitability and applicability ideas than younger children. Older children comprehended that all aunts/uncles, cats and flowers have to die (inevitability) more than younger children do. Furthermore, older children better understood that these entities cannot live forever (applicability). Therefore, we partially supported the first hypothesis, as the findings were consistent with the literature (Panagiotaki et al., 2014; Slaughter \& Griffiths, 2007).

Other cognitive subcategories of death are non-functionality, irreversibility, and causality. While the current literature on children's death concept development indicates that older children show a better understanding on all five cognitive components (Kenyon, 2001; Nguyen \& Gelman, 2002; Rosengren, et al. 2014; Slaughter, 2005), we only found significant differences in the developmental level for two (inevitability and applicability) components. Children understand that a person will not be alive after death (irreversibility) first at around 5 years of age. The order of understanding other components were applicability, inevitability, functionality and causality (Slaughter \& Griffiths, 2007).

Another important result was how death was conceptualized for different entities. Children, regardless of age, understood that all aunts and uncles have to die (inevitability component) more than they comprehended this notion pertaining to cats and flowers. However, they grasped that some cats and flowers cannot live forever (applicability component) more than they did for aunts or uncles. One other finding was the notion of functionality for different age groups. Older children realized that cats and flowers cannot do physical and mental functions once they were dead. However, this was not the case for aunts or uncles. Older children were worse than younger children in understanding that certain functions ceased after death for aunts or uncles. Our findings diverged from the previous studies. Earlier research found that children between 4 and 6 years had similar understanding rates for different entities (humans, animals and plants). However, they found that older children understood applicability better for animals and humans compared to plants (Rosengren et al., 2014). Our results, specifically for applicability, was contradicting where older children failed to understand that some humans cannot live forever. We assume that these results could be related to different developmental patterns and religious reasonings about death, especially the notion of afterlife.

Findings from our study could be interpreted in two ways. One way was to think that older children failed to comprehend cognitive components such as irreversibility and causality and emotional component. The other way to think was that younger children were as mature in these components as older children. Moreover, results could also be explained by the dualistic thinking system (Harris, 2011; Harris \& Giménez, 2005; Richert \& Harris, 2006). The sample consisted of Turkish children, whom were brought up in a society where there is the idea of Allah. Even though there are different micro levels with varying religiousness (or one) in Turkey, children still have access to spiritual notions at meso, exo or macro levels (Bronfenbrenner, 1979). Religious words like Allah, fate, afterlife, if God willing, etc. are ingrained in Turkish language and reference to these notions are very common. As Harris suggested, it was possible that older children thought about death as two sides of the coin; the end of life, and the beginning of a another and eternal life (Harris, 2011; Harris \& Giménez, 2005). Our results showed that older children understood that all humans have to 
die yet they also failed at whether some humans could live forever. While the answer we expected was "no, some humans cannot live forever", the answer older children provided is consistent with the literature. Children matched a more biological conceptualization of death with a more religious comprehension (Astuti \& Harris, 2008; Harris, 2011; Harris \& Giménez, 2005; Richert \& Harris, 2006). Overall, these findings are because it presents diverging patterns from the existing literature.

The study secondly aimed to analyze the importance of parental socialization as children conceptualize death. Talking to their children about the notion was surveyed as one of the means of parental socialization (Maccoby, 1992). In a recent study, interviews were conducted with primary school and high school children on their perception of cancer. All the children were healthy and the primary source of their knowledge related to this disease was their inner circle (Sarkaya Karabudak et al., 2020). Death concept and its development is greatly affected by the parents' socio-cultural views (Panagiotaki et al., 2018), especially for young children. The current study supported the importance of parents' influence in children's cognitive and emotional understanding of death. Children, whose parents communicated about death, were found to score higher in inevitability, irreversibility, and non-functionality components as well as empathy. This study showed the importance of parental socialization in children' s conceptualization of death. Most adults find it hard to explain the concept to their children and avoid providing them answers (Holland, 2008; Ji et al., 2017). However, preventing already curious children from asking questions will only lead to a deep fear of death (Holland, 2008). Future studies can examine other means of parental socialization on death conceptualization such as storytelling or attending the ceremonies together. We speculate that this could enlighten the different learning mechanisms in children's comprehension of death.

There were some limitations in the study that need to be addressed. Our participants were children and their parents living in Turkey. There was a limited number of children but even more limited number of parental surveys. Every parent did not complete the surveys and even if they did, they did not answer each question. The survey included varied questions on death experience of the children, parents' explanations in detail and their suggestions on death education, however, there were not enough answers to base conclusions on. It should also be noted that we used convenience sampling, which could have introduced a selection bias. Therefore, recruiting more children and parents from a more diverse group will allow for statistically more powerful comparisons, provide a more representative sample, together leading to healthier conclusions in the future.

The interview questions that were used in the study were adopted from previous studies (Panagiotaki et al., 2014; Rosengren et al., 2014; Slaughter, 2007). While these questions are used in different cultures and contexts, there are not enough studies that ensure the reliability and validity of these measures either with Turkish populations. We invite the researchers to add on the discussions of the reliability of these questions to measure death understanding. For example, studies investigating the concept of death asked children to make a drawing when they thought of death (Panagiotaki et al., 2018; Vázquez-Sánchez et al., 2019). A culturally applicable tool such as drawing would make a difference in understanding and interpret the developmental patterns of death conception in children. Knowing children's responses at different age groups to death will help plan age-appropriate psycho-social interventions (Erden \& Gürdil, 2009).

In conclusion, we had two motivations for this research. We were able to partially support the first hypothesis; older children would understand death cognitively better, as we have proposed. While we were able to find a significant difference for developmental stages (age-based), out of the five cognitive subcategories we included in the study, we found two cognitive subcategories to be significant. The second hypothesis; testing the influence of parental socialization on the development of the death concept was also 
supported. Children's death understanding significantly develops in early and middle childhood periods (Kenyon, 2001). As the literature suggested (Renaud et al., 2013) and we supported in our study, communicating about the concept is related to better understanding of death cognitively and emotionally. The importance of parent-child communication, especially on a subject like death is very effective for future psychological wellbeing of the person. The development of other abstract or concrete concepts and how they interact with parental socialization could be another research question to follow.

Death is an inevitable event of human life. Unexpected loss could cause negative results for children's well-being (Dettloff, 2012). Knowing the developmental pathways and communicating about death concept accordingly would help children's learning process of the concept and would play a protective role for children's wellbeing in a possible bereavement situation.

\section{References}

Astuti, R., \& Harris, P. (2008). Understanding mortality and the life of the ancestors in rural Madagascar. Cognitive Science: A Multidisciplinary Journal, 32(4), 713-740. doi:10.1080/03640210802066907

Berg, L., Rostila, M., \& Hjern, A. (2016). Parental death during childhood and depression in young adults - a national cohort study. J. Child Psychol. Psychiatry Allied Discip. 57 (9), 1092-1098. http://dx.doi.org/10.1111/jcpp.12560

Brent, S. B., \& Speece, M. W. (1993). "Adult" conceptualization of irreversibility: Implications for the development of the concept of death. Death Studies, 17(3), 203-224.

Bronfenbrenner, U. (1979). The ecology of human development. Cambridge, MA: Harvard University Press.

Calhoun, L. G., \& Tedeschi, R. G. (1999). Facilitating posttraumatic growth: A clinician's guide. London: Lawrence Erlbaum Associates.

Callanan, M. A. (2014). Diversity in children's understanding of death. Monographs of the Society for Research in Child Development, 79(1), 142-150.

Corr, C. A. (1995). Entering into adolescent understandings of death. Bereaved children and teens: A support guide for parents and professionals, 21-35.

Corr, C., \& Balk, D. (2010). Children's encounters with death, bereavement and coping. Springer Publishing Company.

Corriveau, K. H., Chen, E. E., \& Harris, P. L. (2015). Judgments about fact and fiction by children from religious and nonreligious backgrounds. Cognitive Science, 39(2), 353-382.

Çam, O., Bilge, A., \& Keskin, G. (2018). Gidenler ve Geride Kalanlar: İnsan Yavrusu ve Ölüm Yarasını Sarmak. İzmir: Bassaray.

Dettloff, M. (2012). Parentally Bereaved Children: The Impact of Early Loss. Research Paper.

Diyanet İşleri Başkanlığı (DİB) (2014). Türkiye’de Dini Hayat Araştırması. http://www.ceidizleme.org/ekutuphaneresim/dosya/914_1.pdf

Engarhos, P. (2012). The young children's understanding of death: Early conversation and experiences with parents and caregivers. (Master thesis). McGill University, Montreal.

Erden, G., \& Gürdil, G. (2009). Savaş yaşantılarının ardından çocuk ve ergenlerde gözlenen travma tepkileri ve psiko-sosyal yardım önerileri. Türk Psikoloji Yazıları, 12(24), 1-13.

Greeley, A. M., \& Hout, M. (1999). Americans' increasing belief in life after death: Religious competition and acculturation. American Sociological Review, 813-835.

Gutiérrez, I. T., Miller, P. J., Rosengren, K. S., \& Schein, S. S. (2014). III. Affective dimensions of death: Children's books, questions, and understandings. Monogr. Soc. Res. Child Dev. 79(1), 43-61. 
Harris, P. L., \& Giménez, M. (2005). Children's acceptance of conflicting testimony: The case of death. Journal of Cognition and Culture, 5(1), 143-164.

Harris, P. L. (2011). Conflicting thoughts about death. Human Development, 54(3), 160-168. doi:10.1159/000329133.

Holland, J. (2008). How schools can support children who experience loss and death. British Journal of Guidance \& Counselling, 36(4), 411-424.

Hopkins, M. (2014). The development of children's understanding of death. Doctoral Thesis. University of East Anglia, Londres.

Hunter, S. B. (2005). Predictors of children's understanding of death: Age, cognitive ability, death experience, and maternal competence. (Master Thesis). University of Tennessee, Knoxville.

Ji, Y., Cao, Y., \& Han, M. (2017). An Investigation on 3-6-Year-Old Chinese Children's Perception of" Death". Universal Journal of Educational Research, 5(2), 203-208.

Karabudak, S. S., Çalışır, H., \& Öner, H. (2020). Healthy Children's Knowledge and ～Perception on Cancer. Child Indicators Research, 13(1), 279-299.

Kenyon, B. L. (2001). Current research in children's conceptions of death: A critical review. OMEGA - Journal of Death and Dying, 43(1), 63-91. doi:10.2190/0x2b-b1n9-a579-dvk1

Kenyon, P. (2019). Turks examine their muslim devotion after poll says faith could be waning. NPR.https://www.npr.org/2019/02/11/692025584/turks-examine-their-muslim-devotion-after-pollsays-faith-could-be-waning

Köylü, M. (2004). Ölüm olayının çocuklar üzerindeki etkisi ve ‘'Ölüm Eğitimi’’. On Dokuz Mayıs Üniversitesi İlahiyat Fakültesi Dergisi. 95-120.

Lamers, E. P. (1995). Children, death, and fairy tales. OMEGA-Journal of Death and Dying, 31(2), 151-167.

Layne, C. M., Kaplow, J. B., Oosterhoff, B., Hill, R. M., \& Pynoos, R. (2018). The interplay between posttraumatic stress and grief reactions in traumatically bereaved adolescents: When trauma, bereavement, and adolescence converge. Adolescent Psychiatry, 7(4), 266-285.

Legare, C. H., Evans, E. M., Rosengren, K. S., \& Harris, P. L. (2012). The coexistence of natural and supernatural explanations across cultures and development. Child Development, 83, 779-793.

Maccoby, E. E. (1992). The role of parents in the socialization of children: An historical perspective. Developmental Psychology, 28. 1006-101.

Maurer, A. (1966). Maturation of concepts of death. British Journal of Medical Psychology, 39(1), 35-41.

McGuire, S. L., McCarthy, L. S., \& Modrcin. M. A. (2013). An ongoing concern: Helping children comprehend death. Open Journal of Nursing, 3, 307-313.

Miller, P. J., Rosengren, K.S., Gutiérrez, I. T. (2014). Children's' understanding of death: Toward a contextualized and integrated account: I. Introduction. Monogr. Soc. Res. Child Dev. 79 (1), 10-18).

Nguyen, S. P., \& Gelman. (2002). Four and 6-year olds' Biological concept of death: The case of plants. British Journal of Developmental Psychology 20, 495-513.

Nguyen, S. P., \& Rosengren, K. S., (2004). Parental reports on children's biological knowledge and misconceptions. International Journal of Behavioral Development. 411-420.

Özer, S., Sirin, S. R., \& Oppedal, B. (2016). Bahçeşehir study of Syrian refugee children in Turkey. Bahçeşehir Üniversitesi.

Özkök, E. (2019, May 21). Türkiye artık yüzde 99’u müslüman olan ülke değil. Hürriyet (in Turkish). https://www.hurriyet.com.tr/yazarlar/ertugrul-ozkok/turkiye-artik-yuzde-99u-musluman-olan-ulke-degil41220410.

Panagiotaki, G., Hopkins, M., Nobes, G., Ward, E., \& Griffiths, D. (2018). Children's and adults' understanding of death: Cognitive, parental, and experiential influences. Journal of Experimental Child Psychology, 166, 96-115. 
Panagiotaki, G., Nobes, G., Ashraf, A., \& Aubby, H. (2014). British and Pakistani children's understanding of death: Cultural and developmental influences. British Journal of Developmental Psychology, 33(1), 31-44. doi:10.1111/bjdp.12064

Renaud, S. J. (2013). Talking to young children about death: An investigation of parent- child conversations. (PhD Thesis). McGill University, Montreal.

Renaud, S. J., Engarhos, P., Talwar, V., \& Schleifer, M. (2013). Parent- child conservations about death in relation to children' $\mathrm{s}$ fear and understanding death.

Richert, R. A., \& Harris, P. L. (2006). The ghost in my body: Children's developing concept of the soul. Journal of Cognition and Culture, 6(3), 409-427.

Rosengren, K. S., Gutiérrez, I. T., \& Schein, S. S. (2014). Children's' understanding of death: Toward a contextualized and integrated account: IV. Cognitive dimensions of death in context. Monogr. Soc. Res. Child Dev. 79 (1). 62-82.

Sezer, S., \& Saya, P. (2009). Gelişimsel açıdan ölüm kavramı. Dicle Üniversitesi Ziya Gökalp Eğitim Fakültesi Dergisi. 151-165.

Silverman, P. R., \& Worden, J. W. (1992). Children's reactions in the early months after the death of a parent. American Journal of Orthopsychiatry, 62(1), 93-104.

Silverman, P. R., \& Worden, J. W. (1993). Children's reactions to the death of a parent. In M. S. Stroebe, W. Stroebe, \& R. O. Hansson (Eds.), Handbook of bereavement: Theory, research, and intervention (pp. 300-316). Cambridge University Press. https://doi.org/10.1017/CBO9780511664076.021

Slaughter, V. (2005). Young children's understanding of death. Australian Psychologist, 40(3), 179-186. doi:10.1080/00050060500243426.

Slaughter, V., \& Griffiths, M. (2007). Death understanding and fear of death in young children. Clinical Child Psychology and Psychiatry, 12(4), 525-535. doi:10.1177/1359104507080980

Speece, M. W., \& Brent, S. B. (1984). Children's understanding of death: A review of three components of a death concept. Child Development 55. $1671-1686$.

Speece, M. W., \& Brent, S. B. (1996). The development of children's understanding of death. In C. A. Corr \& D. M. Corr (Eds.), Handbook of childhood death and bereavement (pp. 29-50). Springer Publishing Company.

Şimşek Arslan, B., Özer, Z., \& Buldukoğlu, K. (2020). Posttraumatic growth in parentally bereaved children and adolescents: A systematic review. Death studies, 1-13.

Tanhan, F. (2013). Ölüm eğitiminin üniversite öğrencilerinde ölüm kaygısı ve psikolojik iyi olmaya etkisi. YYÜ Ë̆itim Fakültesi Dergisi. 184-200.

UNHCR, The UN Refugee Agency (2019, September). Turkey fact sheet. https://reliefweb.int/sites/reliefweb.int/files/resources/UNHCR\%20Turkey\%20General\%20Fact\%20 Sheet\%20September\%202020.pdf

Vázquez-Sánchez, J. M., Fernández-Alcántara, M., García-Caro, M. P., Cabañero-Martínez, M. J., MartíGarcía, C., \& Montoya-Juárez, R. (2019). The concept of death in children aged from 9 to 11 years: Evidence through inductive and deductive analysis of drawings. Death studies, 43(8), 467-477.

Wass, H., \& Towry, B. J. (1980). Children's death concepts and ethnicity. Death Education, 4(1), 83-86.

Wong, M. (2019). Chinese preschool children's understanding of death. Early Years, 1-16.

Worden, J. W., \& Silverman, P. R. (1996). Parental death and the adjustment of school age children. Omega J Death Dying 33: 91-102.

Yıldız, A. (2004). Çocuk, ölüm ve kayıp. Balıkesir Üniversitesi Sosyal Bilimler Enstitüsü Dergisi, 7(12), 125144.

Yılmaz, S. (2012). 8-13 yaş çocuklarının bilişsel gelişiminde ölüm kavramı. Cumhuriyet Illahiyat Dergisi. 942. 